\title{
Pengaruh Inflasi Dan Tingkat Suku Sbi Terhadap Harga Saham Pada Perusahaan Manufaktur Sub Sektor Food and Beverarge yang Go Public Di Bursa Efek Indonesia
}

\author{
Veny Mayasari ${ }^{\mathbf{1}}$ \\ 1JurusanManajemen, Universitas Tridinanti Palembang \\ Email:veny_mayasari@univ-tridinanti.ac.id
}

\begin{abstract}
The purpose of this research are to determine and analyse the influence of Inflation and SBI rate to Stock Price at Food and Beverage Manufacturing Company that go public in Indonesia Stock Exchange.The population used in this research are all Food and Beverage Manufacturing Company that go public in Indonesia Stock Exchange. The sampling technique is a census, so the sample size used was the entire population that 10 Food and Beverage Manufacturing Company that go public in Indonesia Stock Exchange. Method used in this research is quantitative research. According to the result of regression analysis find that:inflation have significance effects to Stock Price at Food and Beverage Manufacturing Company that go public in Indonesia Stock Exchange, SBI Rate have significance effects to Stock Price at Food and Beverage Manufacturing Company that go public in Indonesia Stock Exchange. (3) Inflation, SBI Rate have significance effects to Stock Price at Food and Beverage Manufacturing Company that go public In Indonesia Stock Exchange
\end{abstract}

Keywords : Inflation, SBI Rate, and Stock Price.

\begin{abstract}
Abstrak
Harga saham umumnya dipengaruhi oleh faktor-faktor mikro dan makro. Faktor mikro yang dapat mempengaruhi harga saham adalah kinerja keuangan perusahaan, kinerja keuangan perusahaan yang lebih tinggi, dapat meningkatkan harga saham dan sebaliknya kinerja keuangan perusahaan yang rendah, dapat menurunkan harga saham. Faktor makro ekonomi yang dapat mempengaruhi harga saham antara lain inflasi dan tingkat suku bunga SBI. Tujuan dari penelitian ini adalah untuk mengetahui dan menganalisis pengaruh Inflasi, suku bunga SBI terhadap harga saham pada perusahaan manufaktur sub sektor Food and Beverage yang go public di Bursa Efek Indonesia. Populasi yang digunakan dalam penelitian ini adalah semua perusahaan manufaktur sub sektor Food and Beverage yang go public di Bursa Efek Indonesia. Teknik sampling yang digunakan adalah teknik sensus, sehingga sampel yang digunakan adalah seluruh populasi, yaitu 10 perusahaan manufaktur sub sektor Food and Beverage yang go public di Bursa Efek Indonesia. Metode yang digunakan dalam penelitian ini adalah penelitian kuantitatif. Hasil analisis regresi menemukan bahwa Inflasi berpengaruh signifikan terhadap Harga Saham pada Perusahaan Manufaktur sub sektor Food and Beverage yang go public di Bursa Efek Indonesia, Tingkat Suku Bunga SBI berpengaruh signifikan terhadap Harga Saham pada perusahaan Manufaktur sub sektor di Food and Beverage yang go public di Bursa Efek Indonesia. Inflasi, Suku Bunga SBI pengaruh signifikan terhadap Harga Saham pada Perusahaan Manufaktur sub sektor Food and Beverage yang go public di Bursa Efek Indonesia
\end{abstract}

Kata Kunci: Inflasi, Suku Bunga SBI, Harga Saham. 


\section{Pendahuluan}

Bursa efek (stock exchange) adalah suatu organisasi yang terorganisasi yang mempertemukan penjual dan pembeli efek, baik secara langsung dan tidak langsung. Pengertian efek adalah setiap surat berharga yang diterbitkan oleh perusahaan, misalnya: surat pengakuan utang, surat berharga komersial (commercial paper), saham, obligasi, right issue, dan waran (Sawir, 2011:189).Efek-efek tersebut dikeluarkan oleh sebuah perusahaan yang memerlukan modal dalam mengembangkan usahanya dan sudah memenuhi persyaratan-persyaratan tertentu yang dikeluarkan oleh lembaga negara yang menangani pasar modal yaitu Badan Pelaksana Pasar Modal (BAPEPAM). Penjualan surat-surat berharga di pasar modal yang sering menjadi sorotan adalah saham. Hal ini dikarenakan surat berharga memberikan hak kepemilikan terhadap perusahaan kepada investor yang menanamkan modalnya di perusahaan tersebut.

Berdasarkan hasil penelitian yang dilakukan oleh Saurabh; L.K Tripathi; and Kirti pada tahun 2012, menjelaskan bahwa: again, all macroeconomic factors that influence future expected cash flows or the discount rate by which the cash flows are discounted should have an influence on the stock price (Saurabh; L.K Tripathi; and Kirti, 2012).Selanjutnya berdasarkan penelitian yang dilakukan oleh OlaOluwa dan Olanrewaju menjelaskan bahwa: In this paper, we have shown that previous exchange rates and inflation rates have significant effects on conditional stock market volatility (Ola Oluwa dan Olanrewaju, 2012).Harga saham merupakan salah satu indikator untuk mengukur tingkat kemakmuran suatu Negara, karena harga saham merupakan cerminan aktivitas investasi di suatu Negara. Pada umumnya harga saham pada pasar modal di Indonesia cenderung berfluktuasi tergantung dari aktivitas pasar modal itu sendiri. Semakin baik aktivitas pasar modal, maka akan menaikkan harga saham dan sebaliknya jika pasar modal mengalami kelesuan, berakibat pada menurunnya tingkat harga saham.

Secara mikro harga saham dipengaruhi oleh kinerja keuangan perusahaan, semakin tinggi tingkat kinerja keuangan perusahaan, maka akan semakin besar tingkat pengembalian saham yang diberikan kepada investor dan sebaliknya semakin rendah tingkat kinerja keuangan perusahaan, maka semakin rendah tingkat pengembalian saham yang diberikan kepada investor. Selain itu harga saham merupakan cerminan dari tingkat keuntungan yang diperoleh dari perusahaanperusahaan yang ada di pasar modal. Bagi investor, harga saham merupakan tolok ukur bagi perusahaan dalam mengukur kinerja suatu portofolio yang dilakukan (Weston dan Copelan, 2010:206).

Selain faktor mikro, kondisi makro ekonomi juga dapat mempengaruhi aktivitas pasar modal. Kondisi makro ekonomi merupakan variabel yang tidak dapat dikendalikan oleh perusahaan, karena kondisi ini di luar jangkauan perusahaan. Faktor-faktor makro ekonomi yang dapat mempengaruhi harga saham antara lain pada sektor keuangan, seperti nilai tukar rupiah, tingkat suku bunga Sertifikat Bank 
Indonesia, dan Inflasi. Sedangkan pada sekrot riil meliputi Gross Domestic Product (GDP), aktivitas Investasi, serta Ekspor dan Impor (Jogiyanto, 2010:138).

Inflasi merupakan kenaikan harga barang dan jasa yang mempunyai pengaruh luas, demikian juga terhadap harga saham di pasar modal. Inflasi berpengaruh positif terhadap harga saham. Jika tingkat Inflasi meningkat, maka harga saham juga ikut meningkat, begitu pula sebaliknya jika tingkat Inflasi menurun, maka harga saham juga ikut turun (Yoopi, 2012:121). Tingkat suku bunga adalah persentase pendapatan yang diterima oleh kreditur dari pihak debitur selama interval waktu tertentu. Perubahan tingkat suku bunga selanjutnya akan berpengaruh negatif terhadap harga saham (Yoopi, 2012:163). Berdasarkan kondisi terjadi serta dalam rangka meningkatkan aktivitas pasar modal di Indonesia dan untuk mengetahui pengaruh faktor makro ekonomi terhadap harga saham pada perusahaan sektor Manufaktur yang go public di Bursa Efek Indonesia, maka penulis tertarik untuk meneliti hal tersebut dengan judul Pengaruh Inflasi dan Tingkat Suku Bunga SBI Terhadap Harga Saham pada Perusahaan Manufaktur Sub Sektor Food and Beverage yang go public di Bursa Efek Indonesia.

\section{Landasan Teori Pasar Modal dan Investasi Saham}

Pasar modal (capital market) adalah pasar keuangan untuk dana-dana jangka panjang dan merupakan pasar yang konkret. Dana jangka panjang adalah dana yang jatuh tempohnya lebih dari satu tahun. Pasar modal dalam arti sempit adalah suatu tempat dalam pengertian fisik yang terorganisasi dengan efek-efek diperdagangkan yang disebut bursa efek (Yoopi, 2012:12). Pengertian bursa efek (stock exchange) adalah suatu organisasi yang terorganisasi yang mempertemukan penjual dan pembeli efek, baik secara langsung dan tidak langsung. Pengertian efek adalah setiap surat berharga yang diterbitkan oleh perusahaan, misalnya: surat pengakuan utang, surat berharga komersial (commercial paper), saham, obligasi, right issue, dan waran (Sawir, 2011:189).

Bursa efek merupakan perusahaan yang jasa utamanya adalah menyelenggarakan kegiatan perdagangan sekuritas di pasar sekunder (Husnan, 2011:30). Di Indonesia terdapat dua bursa, yaitu PT Bursa Efek Jakarta (BEJ) dan PT Bursa Efek Surabaya atau BES. Sekarang ini Bursa Efek Jakarta (BEJ) dan PT Bursa Efek Surabaya (BES) bergabung menjadi satu dan diberi nama Bursa Efek Indonesia (BEI).Investasi saham adalah kita menanamkan uang atau dana dengan cara membeli saham sebuah perusahaan untuk mengharapkan dividen dan proyeksi dari harga dengan cara meramalkan dan memperhitungkan nilai sekarang saham tersebut (Kamarudin, 2012:3).

\section{Inflasi dan Jenis-Jenis Inflasi serta Pengaruh Inflasi terhadap Harga Saham}

Menurut Sawir (2011:218), Inflasi merupakan fenomena ekonomi yang berkaitan dampaknya terhadap makroekonomi agregat : pertumbuhan ekonomi, keseimbangan eksternal, daya saing, tingkat suku bunga dan distribusi pendapatan. Menurut OlaOluwa dan Olanrewaju (2012), Inflation is the percentage change in the 
value of the Wholesale Price Index (WPI) on a year-on year basis.Menurut Susanti (2010:38), bahwa inflasi adalah kenaikan harga umum secara terus menerus dan persisten dari suatu perekonomian. Kenaikan dalam harga rata-rata seluruh barang dan jasa dalam perekonomian harus dibedakan dari kenaikan harga relatif dari barang-barang individual.

Inflasi dapat dibedakan menjadi 4 (empat) macam (Yoopi, 2012:18), sebagai berikut:

a. Inflasi ringan, biasanya bernilai satu digit per tahun.

b. Inflasi sedang, biasanya bernilai antara $10 \%-30 \%$ pertahun.

c. Inflasi berat, biasanya bernilai antara 30\% - 100\% per tahun.

d. HiperInflasi, biasanya bernilai di atas $100 \%$.

Pengukuran di Indonesia diukur berdasarkan penggunaan berbagai indikator, indeks harga konsumen lebih sering menjadi basis perhitungan Inflasi. Indeks harga konsumen mengukur perkembagnan harga barang dan jasa di daerah perkotaan di mana banyaknya barang tergantung pada kota dan tahun dasar. Indeks harga konsumen memmungkinkan kita menganalisis sumber Inflasi menjadi lebih rinci; dengan menggunakan IHK akan diperoleh empat kelompok besar indeks digunakan, yaitu: indeks harga makanan, indeks harga sandang, indeks harga perumahan, dan indeks harga aneka barang dan jasa (Yoopi, 2012:76)Perhitungan tingkat Inflasi menurut IHK dapat dilakukan dengan formula (Susanti, 2010:51), yaitu sebagai berikut:

$$
\Pi=I_{H}-I_{t} K_{t-1} / I_{H K}-1
$$

Keterangan:

$\Pi \quad=$ Inflasi tahun $\mathrm{t}$

$\mathrm{IHK}^{=}$indeks harga $_{\text {konsumen }}$ tahun $_{\mathrm{t}}$ atau $_{\mathrm{t}-1}$

Sementara untuk Inflasi dengan menggunakan deflator PDB dilakukan dengan menghitung terlebih dahulu deflator PDB. Deflator PDB dihitung dengan membagi PDB nominal dengan PDB dengan harga konstan. Cara perhitungan Inflasi tahunan di Indonesia dilakukan dengan berbagai cara antara lain menjumlahkan Inflasi tahunan atau dengan membandingkan bulan desember tahun bersangkutan dengan bulan yang sama tahun lalu atau dengan membandingkan nilai rata-rata indeks bulanan untuk tahun yang bersangkutan dengan indeks rata-rata tahun sebelumnya (Susanti, 2010:52).Perhitungan dengan metode end and end hanya tepat untuk mengukur variabel stock seperti uang beredar atau kekayaan. Sedangkan untuk menghitung variabel flows termasuk indeks daya beli, perhitungan dengan menggunakan perbandingan indeks rata-rata bulanan tahun berlaku dengan tahun sebelumnya 
menjadi lebih tepat. Metode ini lazim digunakan dalam menghitung Inflasi (Susanti, 2010:53).

Nilai Inflasi akan berpengaruh negatif terhadap harga saham. Jika Inflasi tinggi akan mengakibatkan turunnya kepercayaan investor terhadap kondisi pasar modal, sehingga investor akan melakukan penarikan dananya, yang membuat nilai saham jadi turun karena krisis kepercayaan yang dialami investor (Tandelilin, 2010:231). Inflasi memiliki hubungan negatif dengan harga saham. Inflasi meningkatkan pendapatan dan biaya perusahaan. Jika peningkatan biaya produksi lebih tinggi dari peningkatan harga yang dapat dinikmati oleh perusahaan maka profitabilitas perusahaan akan turun. Jika profit yang diperoleh perusahaan kecil, hal ini akan mengakibatkan para investor enggan menanamkan dananya di perusahaan tersebut sehingga harga saham menurun. (Jogiyanto, 2010:387).

Tingginya tingkat Inflasi dapat menurunkan daya beli masyarakat dan juga meningkatnya harga faktor produksi, sehingga dapat mempengaruhi penawaran harga saham perusahaan tersebut dan pada akhirnya berakibat pada pergerakan indeks harga saham (Weston dan Copelan, 2010:325).

\section{Tingkat Suku Bunga dan Jenis-Jenis Tingkat Suku Bunga serta Pengaruh Tingkat Suku Bunga terhadap Harga Saham}

Tingkat suku bunga merupakan suatu ukuran harga sumber daya yang digunakan debitur yang dibayarkan kepada kreditur yang dinyatakan dalam bentuk persentase. (Sunariyah, 2011:134). Suku bunga adalah harga aset finansial. Secara umum, suku bunga dapat dibedakan menjadi suku bunga nominal dan suku bunga riil (Yoopi, 2012:35).Tingkat suku bunga merupakan salah satu variabel penting yang mempengaruhi masyarakat dalam memilih kekayaan yang ingin dimilikinya, apakah dalam bentuk uang, financial assets, atau benda-benda riil seperti tanah, rumah, mesin, barang dagangan dan lain sebagainya. Mana yang memberikan Tingkat suku bunga lebih tinggi akan lebih diminati (Pohan, 2011:7).

SBI merupakan surat berharga yang diterbitkan oleh Bank Central (Bank Indonesia). Penerbitan SBI dilakukan atas unjuk dengan nominal tertentu dan penerbitan SBI biasanya dikaitkan dengan kebijaksanaan pemerintah terhadap operasi pasar terbuka (open market operation) dalam masalah penanggulangan jumlah uang beredar. Dalam penentuan tingkat suku bunga, biasanya tingkat suku bunga SBI selalu tinggi dari tingkat suku bunga perbankan. Hal tersebut dikaitkan dengan tujuan penerbitan SBI yaitu untuk menanggulangi Inflasi. (Kasmir, 2013:259).Suku bunga nominal adalah kewajiban membayar atau hak untuk mendapatkan bunga pada tingkat tertentu tanpa memperhati-kan tingkat Inflasi. Suku bunga nominal terdiri dari buku bunga nominal atas pinjaman dan tabungan. Suku bunga nominal atas pinjaman adalah suku bunga yang disetujui pemilik dana dan peminjam dana pada saat menanda-tangani kontrak pinjaman. 
Suku bunga nominal atas tabungan adalah suku bunga yang ditawarkan pada penabung pada saat tabungan dilakukan. Suku bunga riil adalah suku bunga nominal dikurangi dengan tingkat Inflasi formula suku bunga ril (Yoopi, 2012:36) adalah sebagai berikut :

$$
r=\frac{(1+i)}{(1+p)}
$$

Keterangan:

$\begin{array}{ll}\mathrm{r} & =\text { Suku bunga riil } \\ \mathrm{i} & =\text { Suku bunga Tabungan } \\ \mathrm{p} & =\text { Inflasi }\end{array}$

Tingkat suku bunga menurut pandangan Keynes, tergantung pada dua faktor (Sukirno, 2012:82), yaitu sebagai berikut:

a. Jumlah Penawaran uang yaitu uang yang ada dalam suatu perekonomian dan dapat digunakan oleh masyarakat untuk membeli barang dan jasa.

b. Jumlah permintaan uang yaitu sifat keinginan masyarakat untuk memperoleh uang untuk digunakan dalam transaksi, disimpan dan akan digunakan untuk membiayai kebutuhan mendadak dan untuk spekulasi.

Tingkat suku bunga berpengaruh negatif terhadap harga saham, di mana makin tinggi tingkat suku bunga, keinginan untuk melakukan investasi makin kecil, karena akan menambah pengeluaran investasi dalam bentuk penggunaan dana (cost of capital). Sebaliknya makin rendah tingkat bunga, maka pengusaha akan lebih terdorong untuk melakukan investasi, sebab biaya penggunaan dana (cost of capital) juga makin kecil (Nopirin, 2012:271).Tingkat bunga yang tinggi merupakan sinyal negatif terhadap harga saham. Tingkat suku bunga yang meningkat akan meningkatkan suku bunga yang diisyaratkan atas investasi pada suatu saham. Di samping itu, apabila tingkat suku bunga tinggi, maka para investor akan lebih tertarik untuk menyimpan uang mereka di bank, dan sebaliknya jika tingkat suku bunga rendah, maka para investor akan lebih memilih berinvestasi di saham (Jogiyanto, 2010:391).

\section{Harga Saham}

Indeks harga saham adalah suatu indikator yang menunjukkan pergerakan harga saham. Indeks berfungsi sebagai indikator trend pasar artinya pergerakan indeks menggambarkan kondisi pasar pada saat pasar sedang aktif atau lesu. Di pasar modal, sebuah indeks memiliki lima fungsi, yaitu: sebagai indikator tren pasar; sebagai indikator tingkat keuntungan; sebagai tolok ukur (benchmark) kinerja suatu 
portofolio; memfasilitasi pembentukan portofolio dengan strategi pasif; dan memfasilitasi berkembangnya produk derivatif (Jogiyanto, 2010:167).

Indeks Harga Saham Gabungan adalah indikator gabungan berdasarkan nilai dari seluruh saham yang tercatat di Bursa Efek Indonesia, baik saham biasa maupun saham preferen. (Husnan, 2011:198).Pada Bursa Efek Indonesia (BEI) terdapat enam jenis indeks (Jogiyanto, 2010:170), yaitu sebagai berikut:

a. Indeks Individual

Menggunakan indeks harga masing-masing saham terhadap harga dasarnya.

b. Indeks Harga Saham Sektoral

Menggunakan semua saham yang termasuk dalam masing-masing sektor. Indeks sektoral terbagi atas sembilan sektor yaitu: pertanian; pertambangan; industri dasar; aneka industri; konsumsi; properti; infrastruktur; keuangan; perdagangan, jasa dan manufaktur

c. Indeks Harga Saham Gabungan (IHSG)

Menggunakan semua saham yang tercatat sebgai komponen penghitungan indeks.

d. Indeks LQ-45

Yaitu indeks yang terdiri atas 45 saham pilihan dengan mengacu pada dua variabel yaitu likuiditas perdagangan dan kapitalisasi pasar. Setiap enam bulan, terdapat saham-saham baru masuk ke dalam LQ-45.

e. Indeks Syari'ah atau JII (Jakarta Islamic Index)

Merupakan indeks yang terdiri atas 30 saham yang mengakomodasi syariah investasi dalam Islam atau Indeks yang berdasarkan syariah Islam. Dalam Indeks ini dimasukkan saham-saham yang memenuhi kriteria investasi dalam syariah Islam. Saham-saham yang termasuk dalam Indeks Syariah adalah emiten yang kegiatan usahanya tidak bertentangan dengan syariah seperti :

1) Usaha perjudian dan permainan yang tergolong judi atau perdagangan yang dilarang.

2) Usaha lembaga keuangan konvensional (ribawi) termasuk perbankan dan asuransi konvensional.

3) Usaha yang memproduksi, mendistribusi dan/atau menyediakan barangbarang ataupun jasa yang merusak moral dan bersifat mudarat.

4) Usaha yang memproduksi, mendistribusi serta memper-dagangkan makanan dan minuman yang tergolong haram.

5) Indeks Papan Utama dan Papan Pengembangan yaitu indeks harga saham yang secara khusus didasarkan pada kelompok saham yang tercatat di BEJ yaitu kelompok papan utama dan papan pengembangan.

Untuk menghitung indeks suatu bursa atau industri tertentu ada tiga cara pembobotan yang bisa digunakan (Sawir, 2011:208), yaitu sebagai berikut:

a. Indeks Berdasarkan Harga

Indeks pasar saham berdasarkan harga yang paling populer adalah Dow Jones Industrial Average (DJIA). DJIA sebagai indeks pertama yang berdasarkan harga 
merupakan harga rata-rata dari 30 saham industri besar dan terkenal (blue chips). DJIA dihitung dari total harga 30 saham dan membaginya dengan sebuah pembagi (divisor) yang angkanya disesuaikan setiap kali ada pemecahan saham (stock split) dari saham-saham itu.

b. Indeks berdasarkan Nilai Kapitalisasi Pasar

Indeks berdasarkan nilai memberikan bobot yang lebih besar pada saham yang berkapitalisasi pasar besar dan bukan pada saham yang berharga tinggi. Yang dimaksud dengan kapitalisasi pasar suatu saham adalah jumlah saham yang beredar dikalikan dengan harga pasar saham.

c. Indeks Tidak Tertimbang

Indeks tak tertimbang ini dapat digunakan investor yang memilih saham secara acak (random) dan menginvestasikan jumlah rupiah yang sama besar untuk masingmasing saham dalam portofolionya. Indeks ini mengukur perubahan rata-rata harga saham dalam sampel.

\section{Penelitian Terdahulu}

Berikut ini akan dilampirkan penelitian sebelumnya yang dilakukan oleh beberapa peneliti, sebagai berikut:

a. Hismendi, Abubakar Hamzah, Said Musnadi (2013), dengan judul Analisis Pengaruh Nilai Tukar, SBI, Inflasi dan Pertumbuhan GDP terhadap Pergerakan IHSG di BEI. Hasil penelitian menunjukkan bahwa secara parsial nilai tukar, suku bunga SBI dan pertumbuhan GDP berpengaruh signifikan terhadap pergerakan IHSG, sedangkan inflasi tidak berpengaruh signifikan terhadap terhadap pergerakan IHSG.

b. Umi Mardiyati (2013), Judul penelitian adalah Pengaruh Inflasi, Suku Bunga, Kurs, dan Pertumbuhan PDB terhadap IHSG (Studi Kasus pada Perusahaan Properti yang Terdaftar di Bursa Efek Indonesia. Hasil penelitian menemukan bahwa hanya kurs yang berpengaruh secara signifikan terhadap IHSG, sedangkan tingkat inflasi, suku bunga SBI dan pertumbuhan PDB tidak berpengaruh terhadap IHSG.

c. Ni Made dan Ica (2014), dengan judul penelitian Pengaruh Suku Bunga SBI, Nilai Tukar, Inflasi dan Indeks Dow Jones terhadap IHSG di BEI. Hasil analisis ditemukan suku bunga SBI, inflasi, nilai tukar dan indeks Dow Jones secara simultan berpengaruh terhadap IHSG. Suku bunga SBI, inflasi dan nilai tukar secara parsial berpengaruh negatif signifikan terhadap IHSG. Indeks Dow Jones secara parsial berpengaruh positif dan signifikan terhadap IHSG.

\section{Kerangka Penelitian}

Gambar 1 yang menyajikan Kerangka Pemikiran penelitian ini sebagai berikut:

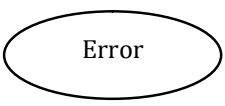



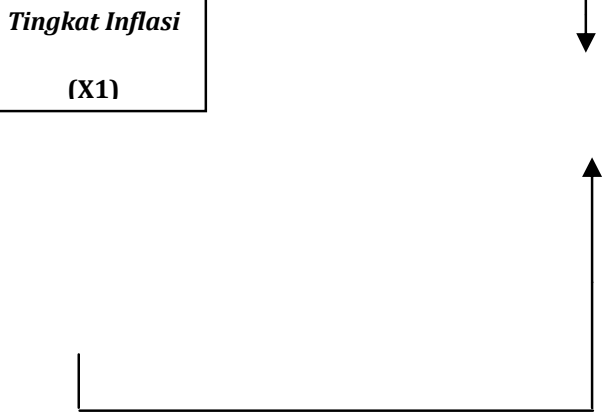

Gambar 1. Kerangka Pemikiran

\section{Hipotesis Penelitian}

Berdasarkan uraian sebelumnya, maka dalam penelitian ini hipotesis yang diajukan adalah :

H1 : Terdapat pengaruh Tingkat Inflasi terhadap Harga Saham pada perusahaan manufaktur sub sektor Food and Beverage yang go public diBursa Efek Indonesia.

H2 : Terdapat pengaruh Tingkat Suku Bunga SBI terhadap Harga Saham pada perusahaan manufaktur sub sektor Food and Beverage yang go public diBursa Efek Indonesia.

H3 : Terdapat pengaruh Tingkat Inflasi \& Tingkat Suku Bunga SBI terhadap Harga Saham pada perusahaan manufaktur sub sektor Food and Beverage yang go public diBursa Efek Indonesia.

\section{Metode Penelitian}

Agar penelitian ini lebih terarah dan terfokus pada objek yang akan diteliti, maka perlu diketahui ruang lingkup penelitian. Adapun ruang lingkup pada penelitian ini adalah hanya terbatas pada perusahaan Manufaktur sub sektor Food and Beverage yang go public di Bursa Efek Indonesia

Perusahaan Manufaktur yang go public di Bursa Efek Indonesia jumlah ratusan, yang terdiri dari sekian banyak jenis manufaktur, mulai dari manufaktur pabrikan, kendaraan bermotor, sampai dengan makanan dan minuman. Pada penelitian ini penulis hanya akan meneliti perusahaan manufaktur sub sektor makanan dan minuman (Food and Beverage) saja, sehingga populasi dalam penelitian ini adalah seluruh perusahaan Manufaktur sub sektor Food and Beverage yang go public di Bursa Efek Indonesia, yaitu:

1. PT. Akasha Wira International Tbk (ADES)

2. PT. Tiga Pilar Sejahtera Food Tbk (AISA)

3. PT. Cahaya Kalbar Tbk (CEKA) 
4. PT. Davomas Abadi Tbk (DAVO)

5. PT. Delta Djakarta Tbk (DLTA)

6. PT. Indofood Sukses Makmur Tbk (INDF)

7. PT. Multi Bintang Indonesia Tbk (MLBI)

8. PT. Mayora Indah Tbk (MYOR)

9. PT. Sekar Laut Tbk (SKLT)

10. PT. Ultrajaya Milk Industry \& Trading Co. Tbk (ULTJ)

Sampel adalah bagian dari populasi yang digunakan untuk memperkirakan karakteristik populasi (Sugiyono, 2012:91). Teknik pengambilan sampel yang digunakan adalah teknik sensus, yaitu teknik pengambilan sampel dengan cara menggunakan seluruh populasi menjadi unit penelitian (sampel jenuh) (Sugiyono, 2012:91). Sehingga besarnya sampel yang digunakan adalah keseluruhan populasi, yaitu sebanyak 10 (sepuluh) perusahaan Manufaktur sub sektor Food and Beverage yang go public di Bursa Efek Indonesia. Adapun metode analisis data yang digunakan adalah sebagai berikut :

a) Analisis Kuantitatif

Analisis Kuantitatif yaitu suatu analisa yang dapat dinyatakan dalam bentuk angka-angka dan dihitung dengan menggunakan rumus statistik.

b) Uji Asumsi Klasik

Menurut Algifari (2009:23) dalam model regresi linier ada beberapa asumsi yang harus dipenuhi agar hasil estimasi efisien yaitu tidak terjadi penyimpangan dan memberikan informasi yang sesuai dengan keadaan nyata.Hal ini juga agar model regresi bersifat BLUE (Best Linear Unbiased Estimated). Dalam penelitian ini asumsi klasik yang digunakan yaitu: uji normalitas, multikolinieritas, heteroskedastisitas, autokorelasi, dan linieritas yang secara rinci dapat dijelaskan sebagai berikut:Pengujian asumsi klasik ini bertujuan untuk mengetahui dan menguji kelayakan atas model regresi yang digunakan dalam penelitian ini. Pengujian ini terdiri dari uji normalisasi, uji multikolonieritas, uji autokorelasi.

c) Uji Instrumen Penelitian

Uji normalitas bertujuan untuk menguji apakah dalam model regresi, variabel penganggu atau residual distribusi normal atau tidak. Model regresi yang baik adalah residualnya berdistribusi normal atau mendekati normal (Umar, 2011:169). Dalam penelitian ini, penulis akan menggunakan uji Lilliefors dengan melihat nilai pada Kolmogorov-Smirnov. Data dinyatakan berdistribusi normal, jika signifikansi pada Kolmogorov-Smirnov lebih besar dari 0,05 (Umar, 2011:171). Sedangkan jika menggunakan grafik Normal P-P Plot, dengan melihat penyebaran item-item pada sumbu diagonal dari grafik tersebut, jika titik-titik yang menyebar disekitar garis diagonal serta penyebarannya mengikuti arah garis diagonal, maka data tersebut dapat dikatakan berdistribusi normal (Umar, 2011:171). 


\section{Hasil dan Pembahasan}

Perusahaan Manufaktur adalah perusahaan yang menjalankan proses pembuatan produk. Sebuah perusahaan bisa dikatakan perusahaan manufaktur apabila ada tahapan input-process-output yang akhirnya menghasilkan suatu produk. Manufaktur adalah suatu cabang industri yang mengaplikasikan peralatan dan suatu medium proses untuk transformasi bahan mentah menjadi barang jadi untuk dijual. Data yang digunakan dalam penelitian ini terdiri dari Harga Saham perusahaan sektor Manufaktur yang go public di Bursa Efek Indonesia, Tingkat Inflasi dan Tingkat Suku Bunga SBI.

Diketahui bahwa harga saham masing-masing perusahaan sektor manufaktur cukup berbeda-beda, seperti PT. Multi Bintang Indonesia Tbk (MLBI) memiliki nilai saham yang paling besar dan selalu mengalami peningkatan, mulai dari harga sebesar Rp. 50.000 per lembar saham pada periode Januari 2014 sampai dengan harga sebesar Rp. 740.000 per lembar saham pada periode Desember 2017. Perusahaan lain yang kondisinya hampir mendekati PT. Multi Bintang Indonesia Tbk (MLBI), adalah PT. Delta Djakarta Tbk (DLTA), yang juga mengalami peningkatan yang cukup baik, dari harga sebesar Rp. 20.000 pada periode Januari 2014 sampai dengan harga sebesar Rp. 255.000 pada periode Desember 2017. Hal ini meng-gambarkan bahwa saham kedua perusahaan ini lebih diminati oleh investor.

Sedangkan harga saham yang paling rendah adalah milik PT.Davomas Abadi Tbk (DAVO), hanya berkisar antara Rp. 50 per lembar saham sampai dengan Rp. 93 per lembar saham. Selain itu harga saham perusahaan ini terkesan tidak mengalami perubahan atau peningkatan yang cukup signifikan. Kondisi ini juga dialami oleh PT. Sekar Laut Tbk (SKLT), di mana harga sahamnya hanya sebesar Rp. 90 per lembar saham pada periode Januari 2014 sampai dengan Rp. 180 per lembar saham pada periode Desember 2017. Walaupun secara umum terlihat mengalami peningkatan, namun jika dilihat secara periodik, peningkatan sangat lamban sekali. Hal ini menggambarkan bahwa saham kedua perusahaan ini kurang diminari oleh investor.

\section{Hasil Pengujian Normalitas Data}

Uji normalitas yang akan digunakan adalah pengujian Lilliefors dengan melihat nilai pada Kolmogorov-Smirnov, di mana jika nilai signifikansi lebih besar daripada 0,05, maka dapat dikatakan bahwa data yang digunakan berdistribusi normal (Umar, 2009:171).Berdasarkan perhitungan dengan menggunakan SPSS for Windows Versi 18.00, diperoleh hasil sebagai berikut

Tabel 1. Hasil Pengujian Normalitas Data 


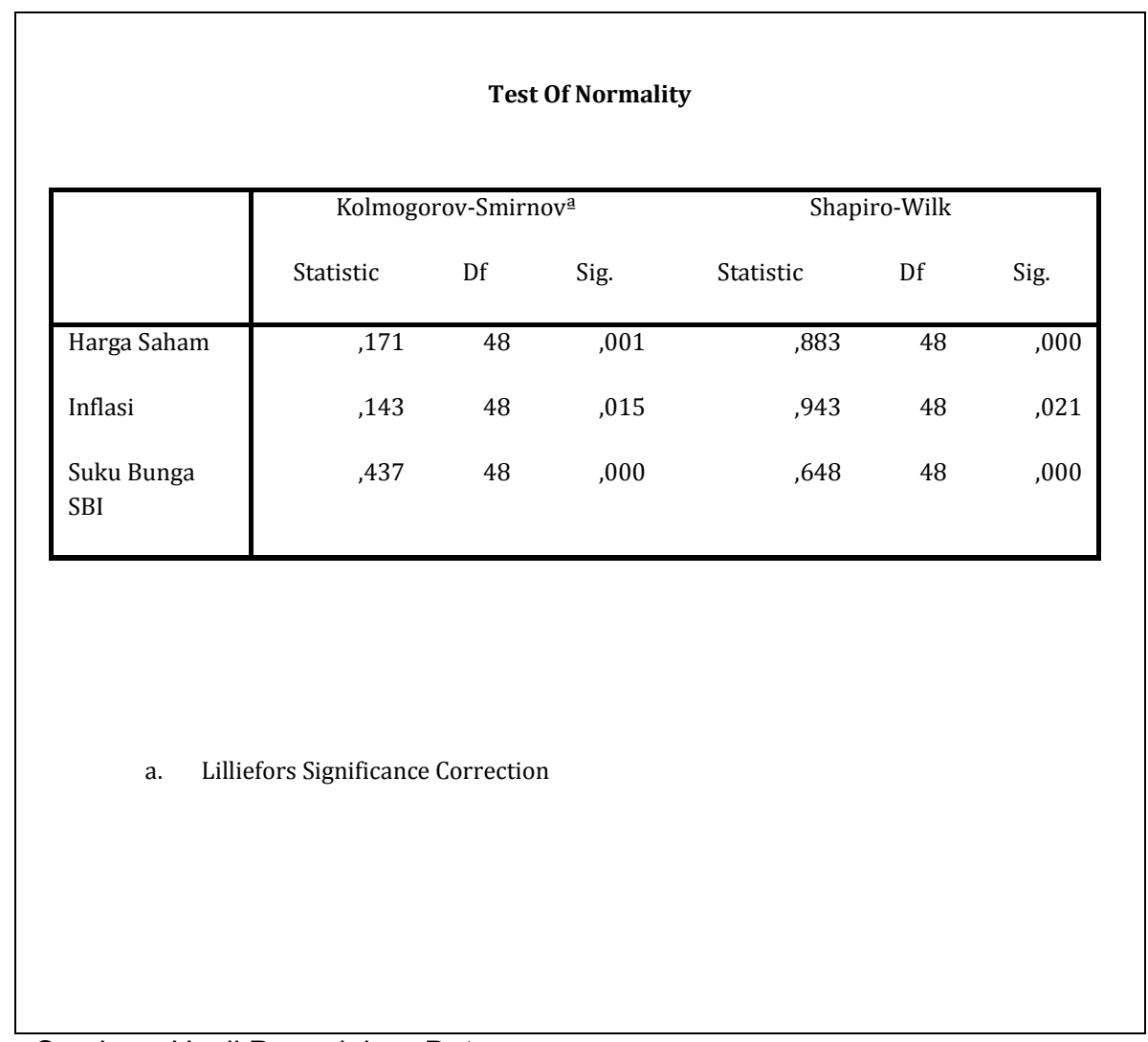

Sumber : Hasil Pengolahan Data

Berdasarkan Tabel tersebut di atas, dapat dilihat bahwa nilai signifikansi Kolmogorov Smirnov untuk variabel Harga Saham (Y) sebesar 0,200*; variabel Inflasi $\left(\mathrm{X}_{1}\right)$ sebesar 0,144; variabel Tingkat Suku Bunga SBI $\left(\mathrm{X}_{2}\right)$ sebesar 0,179. Hal ini berarti bahwa nilai signifikansi masing-masing variabel yang digunakan dalam penelitian ini, lebih besar daripada nilai $\alpha(0,05)$, maka dapat disimpulkan bahwa data-data yang digunakan dalam penelitian ini, terdistribusi dengan normal.

Selain itu, normalitas data juga dapat dilihat dari grafik Normal P-P Plot yang terbentuk. Deteksi normalitas data dengan melihat penyebaran indokator pada sumbu diagonal dari grafik Normal P-P Plot, dengan dasar keputusan, apabaila indokator menyebar di sekitar garis diagonal dan mengikuti arah garis diagonal, maka model regresi linier berganda memenuhi asumsi.

Pengaruh Inflasi terhadap Harga Saham pada Perusahaan Manufaktur Sub Sektor Food and Beverage yang Go Public di Bursa Efek Indonesia

Berdasarkan hasil perhitungan dengan menggunakan SPSS for Windows Versi 18.00, diperoleh hasil sebagai berikut : 


\begin{tabular}{|c|c|c|c|c|c|}
\hline \multicolumn{6}{|c|}{ Coefficients ${ }^{a}$} \\
\hline & \multicolumn{2}{|c|}{$\begin{array}{c}\text { Unstandardized } \\
\text { Coefficients }\end{array}$} & \multirow{2}{*}{$\begin{array}{c}\begin{array}{c}\text { Standardized } \\
\text { Coefficients }\end{array} \\
\text { Beta }\end{array}$} & \multirow[b]{2}{*}{$\mathrm{t}$} & \multirow[b]{2}{*}{ Sig. } \\
\hline & B & Std. Error & & & \\
\hline $1 \quad$ (Constant) & ,049 &, 013 & & 3,637 & 001 \\
\hline Inflasi &,- 565 & ,410 &,- 154 & $-1,161$ & ,245 \\
\hline Suku Bunga SBI &,- 606 & ,444 &,- 188 & $-1,252$ & ,217 \\
\hline
\end{tabular}

Dependent Variable : Harga Saham

Sumber : Hasil Pengolahan Data

Berdasarkan Tabeltersebut di atas, diperoleh koefisien regresi masing-masing variabel, yaitu nilai konstanta (constant) sebesar 0,049; koefisien regresi variabel Inflasi $\left(\mathrm{X}_{1}\right)$ sebesar -0,565; Tingkat Suku Bunga SBI $\left(\mathrm{X}_{2}\right)$ sebesar -0,606. Berdasarkan koefisien-koefisien tersebut di atas, maka dapat dibentuk suatu persamaan regresi linier berganda, yaitu sebagai berikut :

$$
\begin{gathered}
\operatorname{Ln}(\Delta Y)=a+b_{1} \operatorname{Ln}(\Delta \text { Inflasi })+b_{2} \operatorname{Ln}(\Delta \mathrm{SBI})+e \\
Y=0,049-0.565 X_{1}-0.606 X_{2}
\end{gathered}
$$

Berdasarkan persamaan regresi linier berganda tersebut di atas, maka dapat diinterpretasikan, sebagai berikut: nilai konstanta (a) sebesar 0,049; artinya apabila tidak terjadi perubahan Inflasi $\left(\mathrm{X}_{1}\right)$, Tingkat Suku Bunga SBI $\left(\mathrm{X}_{2}\right)$ secara agregat, maka Harga Saham (Y) pada perusahaan sektor Manufaktur yang go public di Bursa Efek Indonesia akan mengalami pergerakan sebesar 0,049 (4,9\%) Maksudnya adalah bahwa jika tidak terjadi Inflasi, Tingkat Suku Bunga SBI tidak mengalami perubahan. Maka peningkatan (growth) harga saham pada perusahaan-perusahaan sektor Manufaktur yang go public di Bursa Efek Indonesia adalah sebesar 0,049\% (4,9\%).

\section{Pengaruh Tingkat Suku Bunga SBI terhadap Harga Saham pada perusahaan manufaktur sub sektor Food and Beverage yang go public di Bursa Efek Indonesia}

Nilai koefisien regresi variabel Tingkat Suku Bunga SBI $\left(\mathrm{X}_{2}\right)$ adalah sebesar 0,606, artinya bahwa pengaruh Tingkat Suku Bunga SBI terhadap Harga Saham perusahaan sektor Manufaktur yang go public di Bursa Efek Indonesia adalah sebesar -0,606; sehingga apabila Tingkat Suku Bunga SBI meningkat sebesar 1\%, maka akan mengakibatkan penurunan Harga Saham pada perusahaan sektor Manufaktur yang go public di Bursa Efek Indonesia sebesar Rp. 0,606. Begitu juga sebaliknya apabila Tingkat Suku Bunga SBI mengalami penurunan sebesar 1\%, maka akan mengakibatkan peningkatan Harga Saham pada perusahaan sektor Manufaktur yang go public di Bursa Efek Indonesia sebesar Rp.0,606.

Nilai thitung pengaruh Tingkat Suku Bunga SBI terhadap Harga Saham, sebesar 2,252; maka thitung $(-2,252)>t_{\text {tabel }}(-2,015)$. Sedangkan nilai signifikan (Sig. $t$ ) 
pengaruh Tingkat Suku Bunga SBI terhadap Harga Saham adalah 0,02, berarti bahwa Sig t $(0,02)<\alpha(0,05)$, sehingga ada pengaruh Tingkat Suku Bunga SBI sterhadap Harga Saham pada perusahaan sektor Manufaktur yang go public di Bursa Efek Indonesia, maka Ho diterima dan Ha ditolak.Berdasarkan hasil perhitungan di atas, menjelaskan bahwa tingkat suku bunga SBI memberikan pengaruh yang negatif (berbanding terbalik) terhadap pergerakan harga saham, serta memberikan pengaruh. Hasil penelitian yang penulis lakukan ini sejalan dengan penelitian yang dilakukan oleh Zhang and Emil(2009), di mana hasil penelitiannya menjelaskan bahwa: economic theory says that there is a negative relationship between interest rates and stock prices.

Namun berbeda dengan hasil penelitian yang dilakukan oleh Mahmudul dan Gazi (2009), hasil penelitiannya menjelaskan bahwa: The relationship between stock prices and interest rates has received considerable attention in the literature. That interest rates have an important impact on stock returns.Kondisi ini sebaiknya menjadi pertimbangan Investor di dalam menanamkan modalnya ke dalam saham perusahaan-perusahaan sektor Manufaktur yang go public di Bursa Efek Indonesia. Jika peningkatan suku bunga SBI masih normal, maka Investor tidak harus ragu dalam menanamkan modalnya pada perusahaan-perusahaan yang dimaksud, namun pada saat peningkatan suku bunga SBI sudah di atas 2 digit, maka hal tersebut harus menjadi warning bagi Investor, agar berhati-hati di dalam menanamkan modalnya.

\section{Pengaruh Inflasi dan Tingkat Suku Bunga SBI terhadap Harga Saham pada perusahaan manufaktur sub sektor Food and Beverage yang go public di Bursa Efek Indonesia}

Dalam menjawab permasalahan tersebut di atas, penulis akan menggunakan uji koefisien determinan ( $R$ Square) dan uji hipotesis F. Uji determinasi digunakan untuk mengetahui kontribusi pengaruh variabel bebas, yaitu Inflasi $\left(\mathrm{X}_{1}\right)$, Tingkat Suku Bunga SBI $\left(\mathrm{X}_{2}\right)$ terhadap variabel terikat, yaitu Harga Saham (Y) pada perusahaan sektor Manufaktur yang go public di BEI.

Berdasarkan hasil olahan data, didapatkan nilai $R$ Square adalah sebesar 0,146 $(14,6 \%)$, namun nilai $\mathrm{R}$ (korelasi) adalah minus (-), angka tersebut berarti bahwa Harga Saham pada perusahaan sektor Manufaktur yang go public di Bursa Efek Indonesia, dapat dijelaskan oleh Inflasi, Tingkat Suku Bunga SBI, sebesar 14,6\%, sedangkan selebihnya sebesar $85,4 \%$, dijelaskan oleh faktor lain yang tidak masuk dalam penelitian ini, seperti kinerja keuangan perusahaan, diantaranya tingkat likuiditas, rentabilitas, solvabilitas, price earning ratio, earning per share, devidend payout ratio, maupun faktor mikro lainnya. Atau faktor-faktor makro lainnya, seperti faktor gross domestic product, faktor politik, keamanan, dan faktor-faktor lainnya. Sehingga jika ada peneliti lain yang ingin mengadakan penelitian pada bidang yang sama, sebaiknya memasukkan faktor-faktor tersebut sebagai variabel penelitiannya, sehingga menghasilkan penelitian yang lebih baik. 
Tabel 3. Hasil Pengujian Hipotesis F (Uji Simultan)

ANOVA

\begin{tabular}{|cc|ccccc|}
\hline \multirow{2}{*}{ Model } & & \multicolumn{1}{|c|}{ Sum of } & \multicolumn{4}{|c|}{ Mean } \\
& & Squares & Df & Square & F & Sig. \\
\hline 1 & Regression &, 053 & 2 &, 018 & - &, $02^{\mathrm{a}}$ \\
& & & & & 2,901 & \\
& Residual &, 314 & 44 &, 007 & & \\
& Total &, 367 & 47 & & & \\
\hline
\end{tabular}

Predictors : (Constant), Suku Bunga SBI, Inflasi

Dependent Variable : Harga Saham

Sumber : Hasil Pengolahan Data

Berdasarkan Tabel 3, maka dapat dilihat bahwa nilai $F_{\text {hitung }}$ untuk variabel Inflasi, Tingkat Suku Bunga SBI terhadap Harga Saham, adalah sebesar -2,501. Sedangkan $F_{\text {tabel }}$ dengan taraf nyata $(\alpha)=5 \%$ dengan penyebut $(\mathrm{n}-\mathrm{k}-1)=(48-3-1)=$ 44; dan pembilang $(\mathrm{k}=3)$ adalah sebesar $\pm \mathbf{2 , 8 2 0}$. Jika $F_{\text {hitung }} \geq F_{\text {tabel, }}$, maka Ho ditolak dan Ha diterima, sedangkan jika $F_{\text {hitung }}<F_{\text {tabel }}$, maka Ho diterima dan Ha ditolak (Umar, 2009:251).

Sehingga $F_{\text {hitung }}(-2,901)>F_{\text {tabel }}(-2,820)$, sedangkan nilai signifikan (Sig F) yaitu sebesar 0,002 , yang berarti Sig $F(0,02)<\alpha(0,05)$, hal tersebut berarti bahwa tanda pengaruh yang antara Inflasi, Tingkat Suku Bunga SBI terhadap Harga Saham pada perusahaan sektor Manufaktur yang go public di Bursa Efek Indonesia, maka Ho ditolak dan Ha diterima.

\section{Kesimpulan}

a. Ada pengaruh variabel Inflasi terhadap Harga Saham pada perusahaan sektor Manufaktur yang go public di Bursa Efek Indonesia.

b. Ada pengaruh variabel Tingkat Suku Bunga SBI terhadap Harga Saham pada perusahaan sektor Manufaktur yang go public di Bursa Efek Indonesia.

c. ada pengaruh yang signifikan variabel Inflasi, Tingkat Suku Bunga SBI, terhadap Harga Saham pada perusahaan sektor Manufaktur yang go public di Bursa Efek Indonesia.

\section{Saran}

1. Bagi investor yang ingin menanamkan modalnya ke dalam saham perusahaanperusahaan sektor Manufaktur. 
a. Investor sebaiknya tidak hanya memperhitungkan tingkat Inflasi, tingkat suku bunga SBI saja, namun juga harus mempertimbangkan faktor-faktor makro lainnya seperti Gross Domestik Brutto (GDB), aktivitas Investasi, aktivitas Ekspor, aktivitas Impor, harga BBM, harga Emas, hasil pertambangan, kondisi Ekonomi, Hutang Luar Negeri, kondisi Keamanan, kondisi Politik, serta faktor-faktor lainnya.

b. Investor juga sebaiknya juga mempertimbangkan faktor mikro, seperti kinerja perusahaan-perusahaan sektor Manufaktur tersebut, misalnya memperhitungkan tingkat Return on Investment (ROI), Earning Per Share (EPS) Price Earning Ratio (PER), Dividend Payout Ratio (DPR), dan rasio-rasio lainnya, agar diketahui persis kondisi keuangan perusahaan tersebut.

c. Investor sebaiknya membentuk portofolio yang optimal dalam menanamkan modalnya pada perusahaan-perusahaan sektor Manufaktur ini, agar terhindar dari resiko kerugian, dan dapat memaksimalkan return saham.

2. Bagi peneliti lain, yang ingin mengadakan penelitian pada bidang dan objek yang sama, sebaiknya menambahkan faktor-faktor makro lainnya seperti tersebut di atas, dan bila perlu mengkolaborasikannya dengan faktor-faktor mikro perusahaan yang dimaksud, diharapkan agar hasil penelitiannya lebih akurat lagi.

3. Bagi perusahaan sektor Manufaktur, seharusnya memperbaiki kinerja keuangannya, kinerja pemasarannya, kinerja produksinya, melakukan kebijakan terhadap harga sahamnya, maupun kebijakan devidennya, hal ini diharapkan dapat menarik minat Investor dalam menanamkan modalnya.

\section{Ucapan Terima Kasih}

Terima Kasih tim peneliti ucapkan kepada Yayasan Pendidikan Nasional Tridinanti (YPNT) Universitas Tridinanti Palembang yang telah memberikan dukungan moril dan bantuan Dana Penelitian Tahun Anggaran 2017/2018 kepada tim peneliti.

\section{Referensi}

Hismendi, Abubakar Hamzah, Said Musnadi. (2013). Analisis Pengaruh Nilai Tukar, SBI, Inflasi dan Pertumbuhan Gdp terhadap Pergerakan Indeks Harga Saham Gabungan di Bursa Efek Indonesia. Jurnal Ilmu Ekonomi Pascasarjana Universitas Syiah Kuala ISSN 2302-0172. Volume 1, No. 2, Mei 2013 - 16.13 Pages pp. 16- 28.

Husnan, Suad. (2011). Dasar-Dasar Teori Portofolio dan Analisis Sekuritas. Edisi Ketiga. Penerbit: UPP AMP YKPN. Yogyakarta

Jogiyanto. (2010). Teori Portofolio dan Analisis Investasi. Edisi Kedua.Penerbit BPFE Yogyakarta. 
Kamarudin, Ahmad. (2012). Dasar-Dasar Manajemen Investasi. Penerbit : PT. Rineka Cipta. Jakarta.

Kasmir, 2013. Bank dan Lembaga Keuangan Lainnya. Edisi Kelima. Jakarta: Penerbit PT. Raja Grafindo Persada Indonesia.

Neny Mulyani. (2014). Analisis Pengaruh Inflasi, Suku Bunga, Nilai Tukar Rupiah, dan Produk Domestik Bruto terhadap Jakarta Islamic Index. Jurnal Bisnis dan Manajemen Eksekutif Vol. 1 No. 1, 2014, artikel 10.

Ni Made Anita Dewi Sudarsana. Dan Ica Rika Candraningrat. (2014). Pengaruh Suku Bunga SBI, Nilai Tukar, Inflasi dan Indeks Dow Jones terhadap IHSG di BEI. Jurnal Akuntansi dan Manajemen (JAM) April 2014: 53-65Vol. 25, No. 1.

Nopirin. (2012). Ekonomi Moneter. Buku Satu. Edisi Keempat. Penerbit BPFE.Yogyakarta.

OlaOluwa S. Yaya and Olanrewaju I. Shittu. (2012). On The Impact of Inflation and Exchange Rate on Conditional Stock Market Volatility: A Re-Assessment. American Journal of Scientific And Industrial Research. Department of Statistics, University of Ibadan, NigeriaISSN: 2153-649X doi:10.5251/ajsir.2010. 1.2.115.117.

Sugiyono. (2012). Metode Penelitian Bisnis. Cetakan ke Delapan. Penerbit AlfabetaBandung.

Sukirno, Sadono. (2012). Pengantar Teori Makro Ekonomi. Cetakan Ketiga Belas. Edisi Kedua.Penerbit PT. Raja Grafindo Persada Indonesia. Jakarta.

Susanti, Hera. (2010). Indikator-Indikator Makroekonomi. Edisi Ketiga.Penerbit Lembaga Penerbit Fakultas Ekonomi Universitas Indonesia. Jakarta.

Umar, Husein. (2011). Metode Riset Bisnis. Cetakan Kedua.Penerbit PT Gramedia Pustaka Utama Indonesia. Jakarta.

Umi Mardiyati. (2013). Pengaruh Inflasi, Suku Bunga, Kurs, dan Pertumbuhan PDB terhadap IHSG (Studi Kasus pada Perusahaan Properti yang Terdaftar di Bursa Efek Indonesia). Jurnal Riset Manajemen Sains Indonesia (JRMSI) Vol. 4, No. 1. 
ISSN 2657-1080

ISSN 1858-3687

Akuntansi dan Manajemen Vol.14, No.2, 2019

Yoopi Abimanyu. (2012). Memahami Kurs Valuta Asing.Penerbit Fakultas Ekonomi Universitas Indonesia. Jakarta. 